American Journal of Applied Sciences 1 (4): 295-301, 2004

ISSN 1546-9239

(C) Science Publications, 2004

\title{
A Research on Forest Road Planning and Projecting by Inroads Software in Bolu Region of Turkey
}

\author{
Murat Demir and Tolga Ozturk \\ Department of Forest Construction and Transportation, Faculty of Forestry \\ University of Istanbul, 34473 Bahcekoy/Sariyer, Istanbul, Turkey
}

\begin{abstract}
The computer software and hardware is extensively and effectively used especially in many countries of the world for the solution of complex problems. The facilities offered by the computer technology is used to great extend in forestry also as in numerous other areas. With this purpose, this research includes a study of forest road construction activities in Turkey, basic principles of planning forest roads, digital terrain models and forest road planning which were integrated in the applied sample at the Mengen district of Bolu in Turkey. Analysis of slope and aspects have been made by digitization of maps and InROADS SelectCAD Version 8.0 software. The road network and the transportation planning of forest have been done by using above mentioned and general facts.
\end{abstract}

Key words: Turkey, Forest Roads Planning, Digital Terrain Model, Inroads Software

\section{INTRODUCTION}

It is known that exploitation of forests in rough terrain is highly impacted by transportation facilities. Consistent exploitation and protection of forests; and making the direct benefits of forests available to public, are primarily depended on a well arranged road network and transportation plan for such forests ${ }^{[1]}$.

The computer software and hardware is extensively and effectively used especially in the developed world for the solutions of complex problems. The facilities offered by the computer technology are used to great extend in forestry also as in numerous other areas. The accelerated development in computer software and hardware particularly during the last few decades has made topical the use of such systems as a significant tool in the realization of space analysis, planning, management and decision making. With the assistance of digital terrain models to be developed out of such digital data, it is possible to draw up land cross sections required to plan forest road constructions for serving the purpose of administrative forestry works, transportation of raw logs, forest protection, particularly keeping conflagrations and pest invasions under control; and to make projects for installation locations of skylines which are more economic for extracting the basic product (trunk) out of forests in steep areas and highlands, access of which is either impossible or highly expensive. Furthermore, slope maps developed out of digital terrain models are very useful in erosion detection activities which is highly significant for Turkey. With this purpose, this research includes a study of forest road construction activities in Turkey, the basic principles of planning forest roads, digital terrain models and forest road planning which were integrated in an applied sample at the Bolu-Mengen district of Turkey ${ }^{[2-5]}$.

\section{MATERIALS AND METHODS}

Turkey, with $97 \%$ of its land in Asia and 3\% in Europe continents, is located between $42^{\circ} 06^{\prime}-35^{\circ} 51^{\prime} \mathrm{N}$ latitude and $25^{\circ} 40^{\prime}-44^{\circ} 48^{\prime} \mathrm{E}$ longitudes. Turkey is surrounded by the Mediterranean, the Black Sea, the Marmara and the Aegean Sea, has an area of 77945200 hectares and coasts of $8333 \mathrm{~km}$ long. This width along with large distances of over $1600 \mathrm{~km}$ in East-West, and changing between 475-650 km in North-South direction, as well properties such as location, relief and climate have caused the formation of different geographical regions within the country boundaries. (Fig. 1) ${ }^{[6]}$. As of the end of 2003, the total forest area in Turkey is 20703122 hectares. This figure is $26.6 \%$ of Turkey's area. High quality forests and coppice forests spread over 10547987 hectares account for $50.9 \%$ of the total forest area, coppice forests spread over 10155135 hectares account for $49.1 \%$ of the total forest area. According to 2003 figures, the percent of coniferous forest in the total forest area is 53.9 and that of deciduous forest is 46.1. Production capacities are approximately $12039718 \mathrm{~m}^{3} /$ year in high quality forests and $8837705 \mathrm{~m}^{3 / y e a r}$ in coppice forests, respectively ${ }^{[7]}$.

Until recently, the forests in Turkey have encountered excessive interventions at diverse levels and densities in order to meet the country's needs for firewood. These detrimental interventions started generally in forest lands which provided easy access or transportation, and continued for long causing damage to some parts of the natural structure of our forests. Forest roads are the most important infrastructure for forestry operations. But, if does not good plan; they caused technical, economical and environmental problems. Though the construction of forest roads has been subject to certain regulations under Forest Act, which was first introduced in 1937 in Turkey, the forest 
road construction operations have resulted in nonsystematic forest roads since these construction operations were based only on obtaining firewood easily, economically and rapidly until 1963 which was the beginning of the planned period. For this reason, the forest road construction operations in Turkey should be evaluated in two categories: planned period and unplanned period. The forest roads constructed in Turkey prior to the planned period where, as mentioned above, were constructed at random on easily accessible forest lands in order to rapidly transport cut woods and to meet daily needs, thus there appeared a substantial tendency to construct roads rapidly, easily and economically. So, there have been many forest roads constructed failing to be compliant with the standards in relation to forest road declivity and location and also failing to ensure that forest is managed properly. The planning of the systematic forest road network over the unplanned period was commenced in 1964 in Turkey and completed in 1974. Also in this period, a total road of $144425 \mathrm{~km}$ was planned by taking into account only fertile forest lands in Turkey. However, the developments in forestry science and practices and the production technologies and techniques as well as the results obtained from rational forestry and plan implementation requirements entailed revision of such plans. Basing on a plan prepared in accordance with that new understanding, the need for forest roads in total in Turkey was $201810 \mathrm{~km}$, and that $133693 \mathrm{~km}$ portion of which, corresponding to $66.25 \%$, was constructed by the end of 2003. It is aimed that the construction of the planned forest roads and the completion of forest road structures of all forest roads will be achieved within 20 years. As a result, today, a substantial part of the forest in Turkey has been provided with forest roads constructed basing on a plan and transportation by truck on such roads has almost been the one and only choice. Today, the concepts like the digital map, digital terrain model, the geographic information systems, and the land information systems have gained an important role. Turkish General Directorate of Forests has initiated the works in this field, in order to be able to realize all kinds of services and studies (such as road planning, Cadastre, forest management planning) more rapidly, efficiently and economically; and to produce digital data that are necessary for the coordination between various units which apply these techniques. This unit named "Forest Information System" (FIS) has been established for all kinds of demands of the people who deal with the matter ${ }^{[5,6,8]}$.

Today, computer software and hardware facilities will be extensively advantageous with respect money, personnel and time for the Turkish Forestry Administration which is an institution building or contracting an average of 3500-4000 km forest roads per year in Turkey. When the amounts to be saved out of the utilization of computers for forest road plans and projects is considered, it will be observed that the return on investment with initial high outlays for the system (software and hardware etc.) would be achieved in a short time. On the other hand, activities are going on for the digital maintenance of basic supporting maps with the purpose of ensuring a more accelerated, more economic and more effective performance of multipurpose forestry services and implementations of Turkish Forestry Administration ${ }^{[9-11]}$.

With this purpose, digital terrain models and forest road planning which were integrated in an applied sample at the Mengen district of Bolu in Turkey. Mengen district is located between $40^{\circ} 53^{\prime} 45^{\prime \prime}-41^{\circ} 00^{\prime}$ $30^{\prime \prime} \mathrm{N}$ latitude and $31^{\circ} 53^{\prime} 40^{\prime \prime}-32^{\circ} 03^{\prime} 30^{\prime \prime} \mathrm{E}$ longitudes and 55 kilometers distance from center of Bolu (Fig. 2). The research area average elevation is $450-1400 \mathrm{~m}$ and average slope is $40-80 \%$. The meteorological climate elements of the research area are under influence of West Black Sea Region. The average annual rainfall here is $536.4 \mathrm{~mm}, 31.12 \%$ of annual rainfall drops in winter, $28.62 \%$ in spring, $18.83 \%$ in summer and the remaining $21.23 \%$ in the fall. There are Pinus nigra, Abies sp., Fagus sp., Quercus sp., Carpinus betulus, Populus sp., Tilia sp., Platanus sp., Acer sp. and Cornus sp. in the research area ${ }^{[4,7,12]}$.

Preparation of the Road Network Plan: According to the existing forest management plan of Mengen district, total research area is 8801 hectares, 7518 hectares of which are forested. Total area of reforestation has been designated as 1725.5 hectares in the forest management plan. The average wealth per hectare of the research area is $188.78 \mathrm{~m}^{3} /$ hectare, which is below 250 $\mathrm{m}^{3} /$ hectare. Thus, forest roads spacing should be 1000 $\mathrm{m}$ and road density should be $10 \mathrm{~m} /$ hectare according to the basic principles of planning forest road network. Accordingly, with the consideration of only the areas to be reforested and the wealth per hectare, total length of forest roads should be $92+435 \mathrm{~km}$ given a road density of $20 \mathrm{~m} /$ hectare at 1725.5 hectares $(34+510 \mathrm{~km})$; and a road density $10 \mathrm{~m} /$ hectare at 5792.5 hectares $(57+925$ $\mathrm{km})$. It is decided that all roads which will constitute the road network of research area, will be constructed in accordance with the B type forest road standards and covered with gravel. The studies concerning the preparation of the road network plan started with the assessment of the roads' characteristics such as slope, width, curb radius and structures. The cardinal points related to the routes are determined through studies conducted on the land and marked on a 1 / 25000 scale ortho photo maps. The length of the existing roads in the research area is $37+926 \mathrm{~km}$. In addition, these roads coded 218, 218-1, 218-2, 218-3, 220 have been included in the new road network, provided they are repaired. Attention is paid in not exceeding standard values determined for slight slope (9-10\%) in the studies on the routes of roads constituting the road network. A slope at $9 \%$ was allowed provided it became compulsory and only in short distances. 


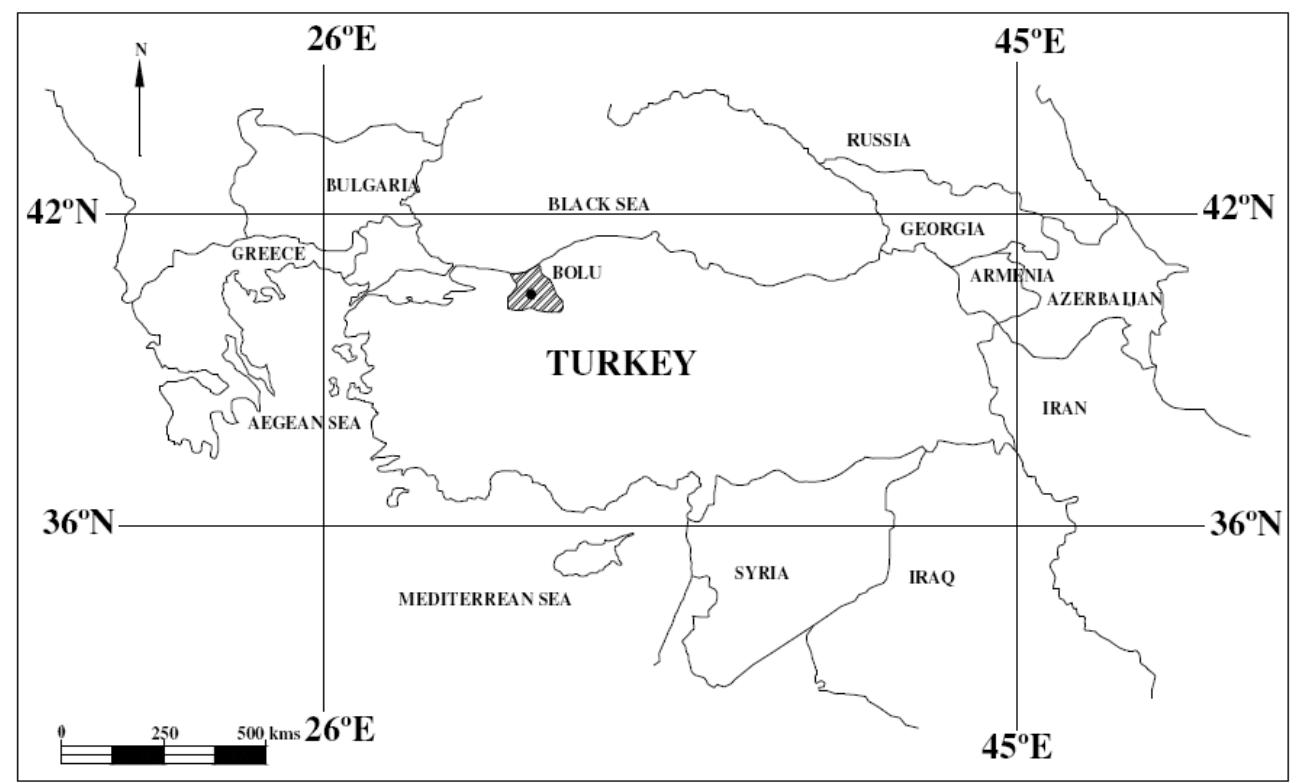

Fig. 1: The Location Bolu Region of Turkey

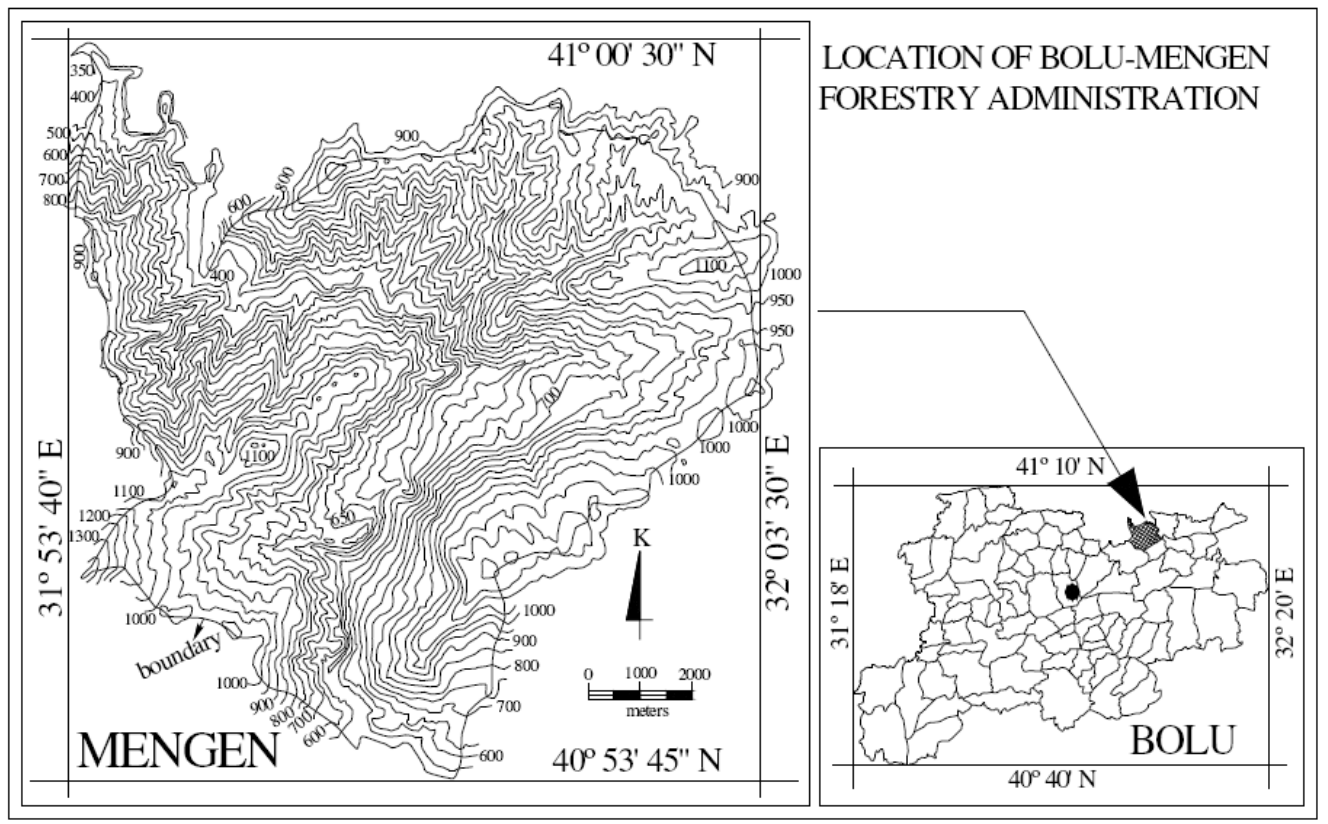

Fig. 2: The Location of Mengen District of Bolu in Turkey

At least 2\% slope was formed in order to ensure sufficient drainage all along the roads. Reverse slopes were avoided as much as possible during the route studies but only reverse slopes not exceeding 6-7\% in short distances were allowed due to negative circumstances and for attaining important cardinal points.

Preparation of the Digital Terrain Model: The data consisting of heights and coordinates of the research area were obtained from 1/25000 scale orthophoto black-white maps. In order to affect the analysis of the digital terrain model and declivity and aspect of the said land, contour lines of the land were copied from the orthophoto maps. The contour lines copied were digitized into a DXF format by using the AutoCAD 2002 and with the help of the Drawing Board III model digitization tablet. The existing height data were transferred to this map by effecting necessary corrections to InROADS SelectCAD software. With the help of the digitized terrain model created, the Terrain Analysis module in InROADS SelectCAD software. 

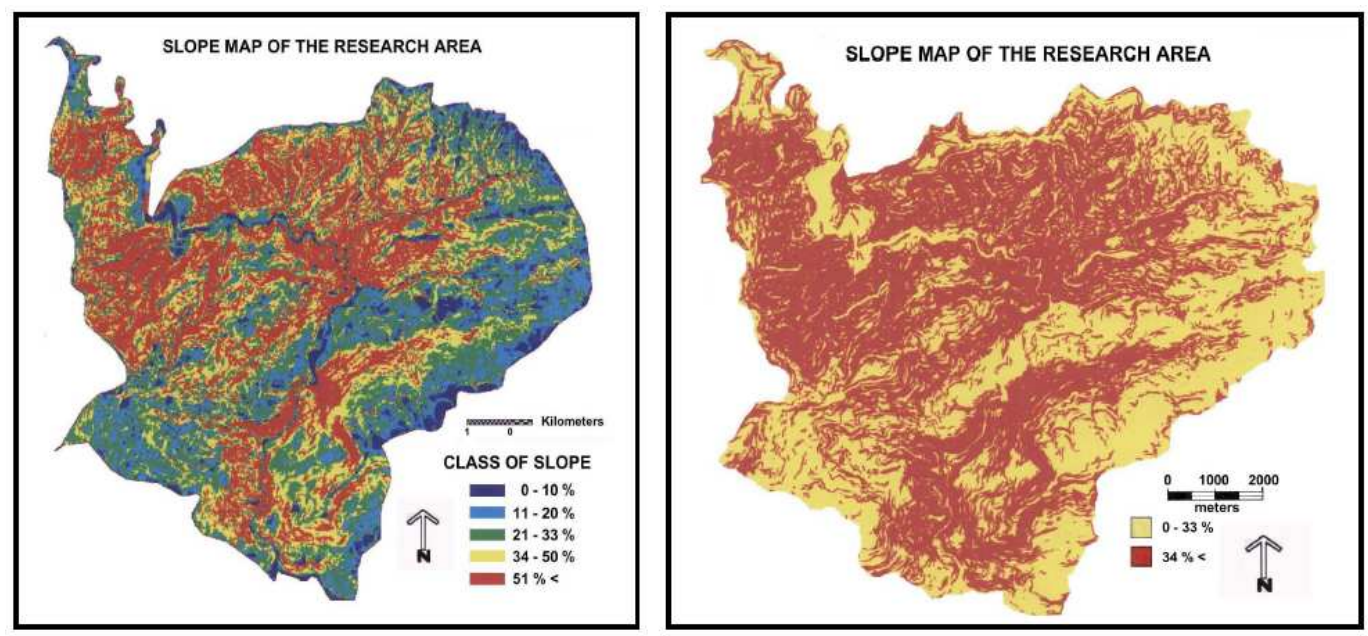

Fig. 3: Slope Maps of the Research Area

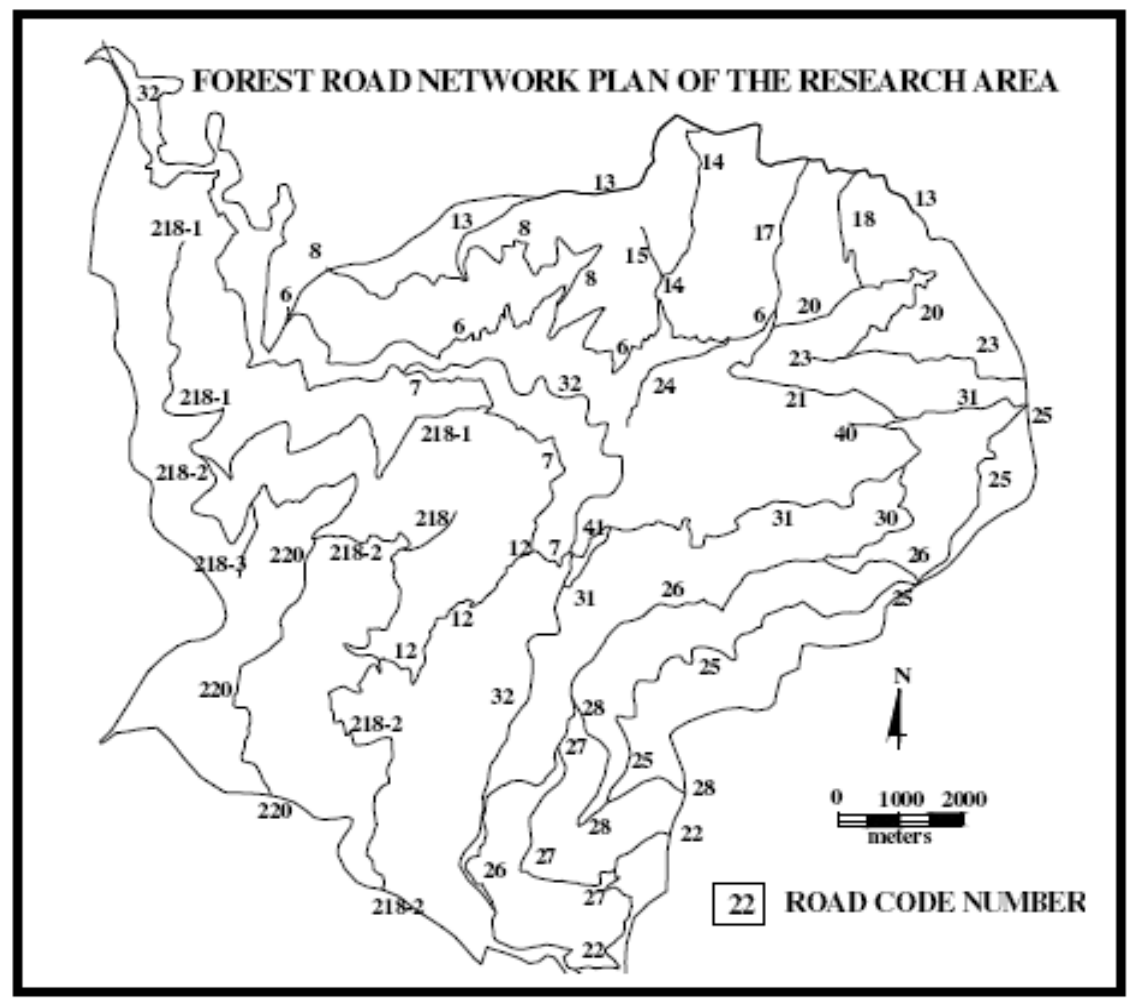

Fig. 4: Forest Road Network Plan of the Research Area

Formation of the Slope and Aspect Maps: After digital terrain model created, the Terrain Analysis module in InROADS SelectCAD software can conduct the slope and aspect analysis. At this stage, first the aspect analysis was conducted. By using it as an input, the digital terrain model which was created for that purpose, was introduced in the Terrain Analysis module. The flat terrains, along with aspect in 8 directions, were created in the file in new format by choosing the option 8-Directional existing in the module. The same module was also used to create the slope categories. In this process, the percent option was chosen by employing the Slope command. At the end of the operation, slope categories between of 0$190 \%-1 \%$ variations were created. Later, the variations of slope categories were joined together by employing the Recode command basing on the slope categories to be created. For instance, the slope categories between $0-10 \%$ were assessed as one single category by including them in the same category. As a result, a new file and slope map have been created (Fig. 3-5 and Table 1-2). 


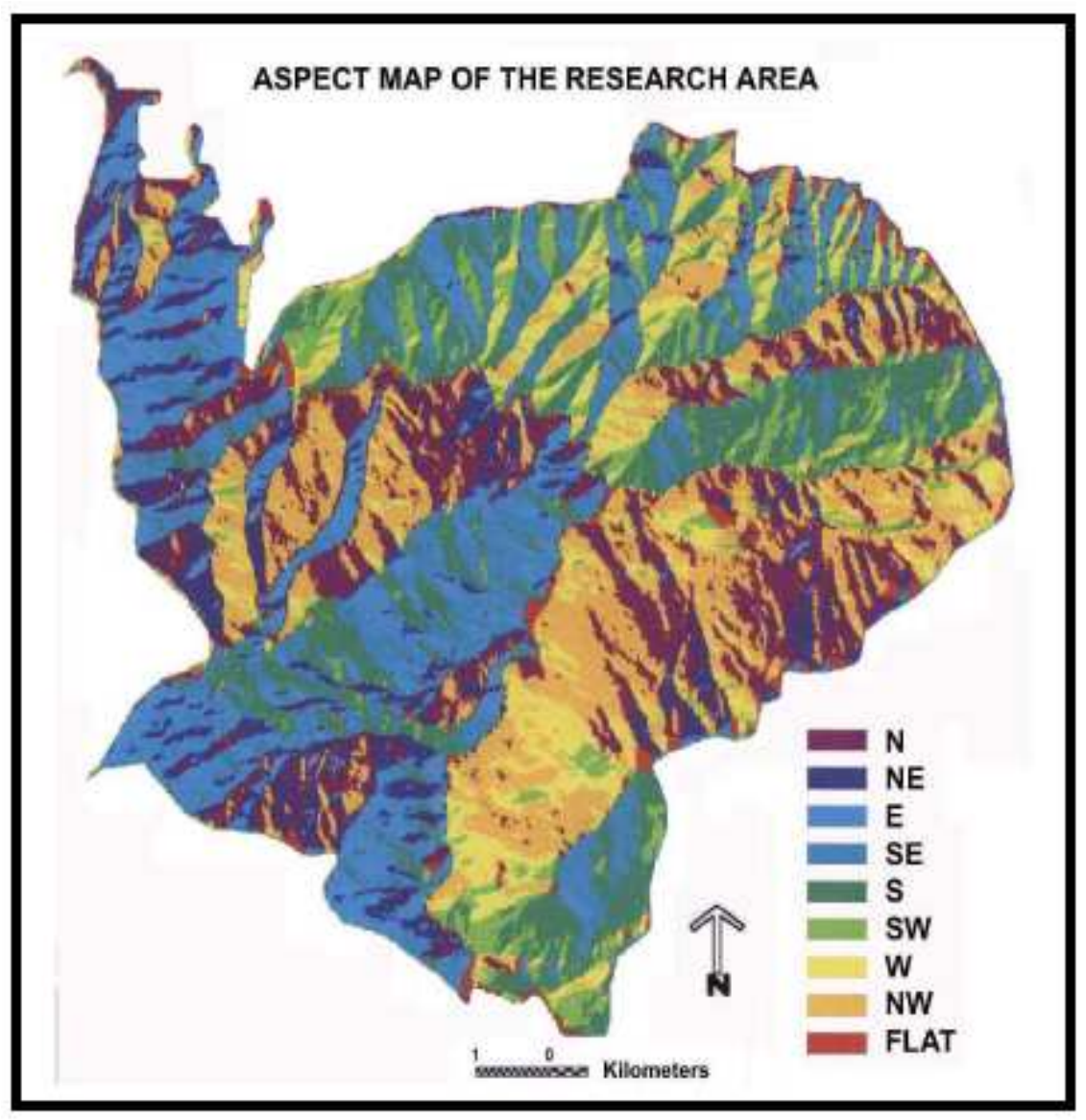

Fig. 5: Aspect Map of the Research Area

Table 1: The Results of Slope Analyses of the Research Area Slope Groups (\%) Area

\begin{tabular}{llclll}
\hline Slope Groups (\%) & $\begin{array}{l}\text { Area } \\
\text { (Hectares) }\end{array}$ & Proportion $(\%)$ & Slope Groups $(\%)$ & $\begin{array}{l}\text { Area } \\
\text { (Hectares) }\end{array}$ & Proportion $(\%)$ \\
\hline $0-10$ & 593.28 & 6.74 & $0-33$ & 4039.20 & 45.89 \\
$11-20$ & 1319.04 & 14.99 & $34<$ & 4761.80 & 54.11 \\
$21-33$ & 2126.88 & 24.17 & & & \\
$34-50$ & 2410.56 & 27.39 & & & \\
$51<$ & 2351.24 & 26.71 & Total & 8801.00 & 100.00 \\
Total & 8801.00 & 100.00 & & & \\
\hline
\end{tabular}

Table 2: The Results of Aspect Analyses of the Research Area

\begin{tabular}{lcc}
\hline Aspects & Area (Hectares) & Proportion $(\%)$ \\
\hline North (N) & 1188.17 & 13.50 \\
North East (NE) & 775.47 & 8.81 \\
East (E) & 1128.24 & 12.82 \\
South East (SE) & 1134.15 & 12.89 \\
South (S) & 1142.67 & 12.98 \\
South West (SW) & 688.40 & 7.82 \\
West (W) & 928.45 & 10.55 \\
North West (NW) & 1532.33 & 17.41 \\
Flat Area & 283.12 & 3.22 \\
Total & 8801.00 & 100.00 \\
\hline
\end{tabular}

\section{RESULTS AND DISCUSSION}

With the road network to be constructed, the forest will be used in the most optimum way possible and through utilization at maximum level, be very beneficial in terms of environment. Because, by way of digital terrain modeling and assessment of slope thereat, the usage of a land in an impropriate way will be prevented and besides, the most beneficial road will have been planned in technical, economical and ecological aspects. Accordingly, optimum transportation plans will be established in line with this optimum road planning.

The data consisting of heights and coordinates of the research area were obtained from 1/25000 scale orthophoto black-white maps. In order to affect the analysis of the digital terrain model and declivity and aspect of the said land, contour lines of the land were copied from the orthophoto maps. Slope and aspect maps are used intensively in making the road network and transportation plans by InRoads software (Fig. 3-5). Slope rating 33\% and higher area is formed of $54.11 \%$ and slope rate $33 \%$ lower area is formed of $45.89 \%$ of the research area (Table 1). 


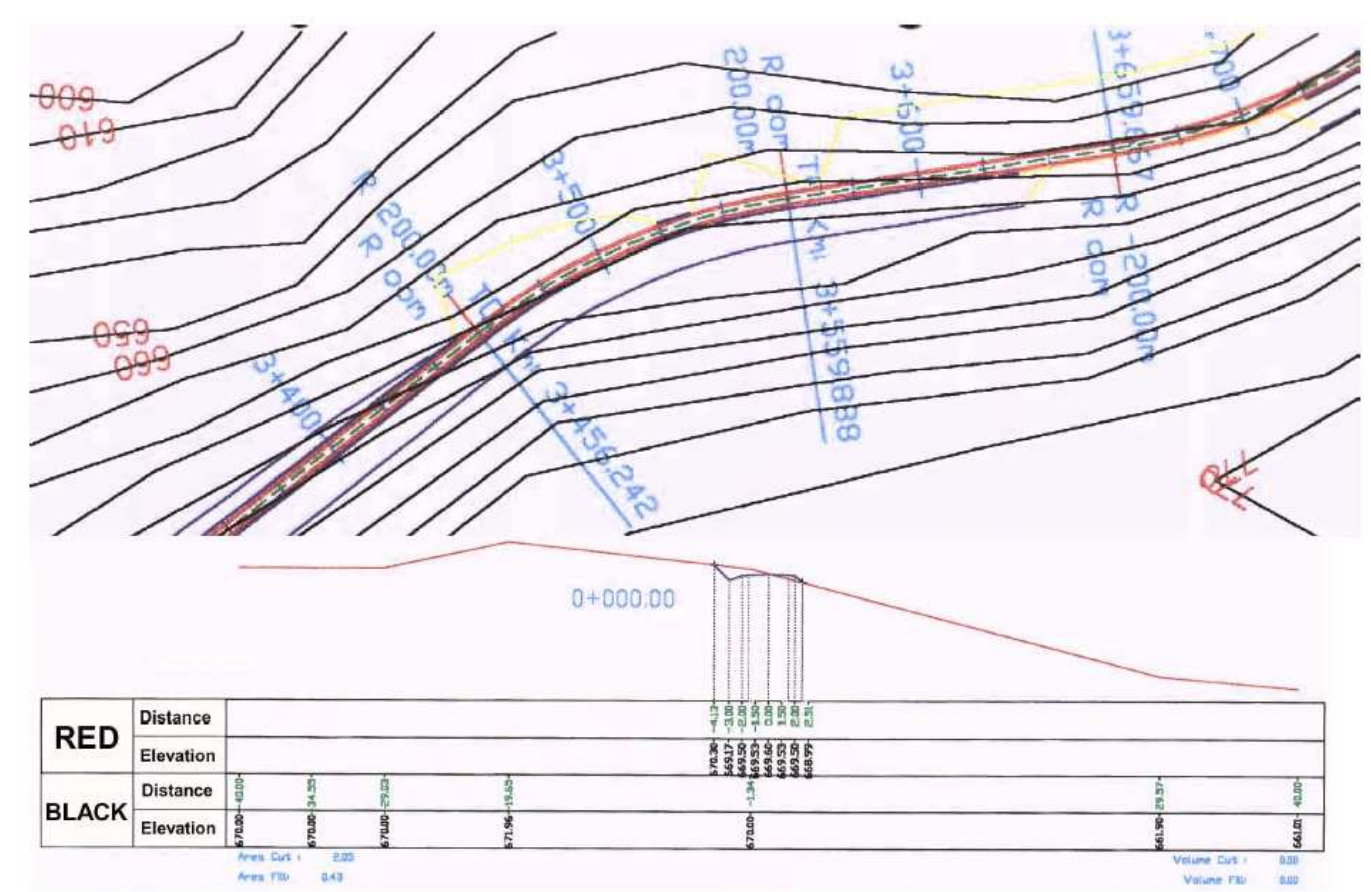

Fig. 6: Sample Forest Road Route and Cross Section

Table 3: The Cut and Fill Volumes of Forest Roads of the Research Area

\begin{tabular}{|c|c|c|c|c|c|c|c|}
\hline $\begin{array}{l}\text { Road } \\
\text { Code } \\
\text { Number }\end{array}$ & $\begin{array}{l}\text { Road } \\
\text { Length } \\
(\mathrm{Km})\end{array}$ & $\begin{array}{l}\text { Total Cut } \\
\text { Volumes } \\
\left(\mathrm{m}^{3}\right)\end{array}$ & $\begin{array}{l}\text { Total Fill } \\
\text { Volumes } \\
\left(\mathrm{m}^{3}\right)\end{array}$ & $\begin{array}{l}\text { Road Code } \\
\text { Number }\end{array}$ & $\begin{array}{l}\text { Road } \\
\text { Length } \\
(\mathrm{Km})\end{array}$ & $\begin{array}{l}\text { Total Cut } \\
\text { Volumes } \\
\left(\mathrm{m}^{3}\right)\end{array}$ & $\begin{array}{l}\text { Total Fill } \\
\text { Volumes } \\
\left(\mathrm{m}^{3}\right)\end{array}$ \\
\hline $5-\mathrm{Aug}$ & $0+900$ & 993.200 & 521.350 & 21 & $3+684$ & 9088.560 & 6233.910 \\
\hline $218-1$ & $0+986$ & 22511.800 & 23596.300 & 22 & $3+429$ & 9754.170 & 7481.000 \\
\hline $218-2$ & $2+828$ & 23697.600 & 19691.300 & 23 & $3+121$ & 6365.087 & 8163.465 \\
\hline $218-3$ & $1+018$ & 1355.434 & 953.182 & 24 & $1+973$ & 2887.734 & 2714.950 \\
\hline 220 & $4+068$ & 5783.378 & 5171.725 & 25 & $9+140$ & 24165.450 & 21766.550 \\
\hline 6 & $1+900$ & 21228.600 & 18002.400 & 26 & $9+430$ & 22486.500 & 23752.100 \\
\hline 7 & $4+332$ & 6604.526 & 7233.650 & 27 & $3+222$ & 9060.740 & 6679.800 \\
\hline 8 & $6+600$ & 13964.950 & 13958.100 & 28 & $3+620$ & 6803.700 & 10202.470 \\
\hline 12 & $3+817$ & 10928.430 & 7245.900 & 30 & $2+252$ & 5413.120 & 2862.310 \\
\hline 13 & $8+230$ & 15181.300 & 17688.750 & 31 & $6+200$ & 12735.200 & 10753.850 \\
\hline 14 & $2+330$ & 5020.835 & 5163.050 & 32 & $22+436$ & 90672.850 & 78684.600 \\
\hline 15 & $0+718$ & 1130.250 & 3515.550 & 40 & $0+485$ & 677.575 & 1572.750 \\
\hline 17 & $3+000$ & 5679.850 & 6686.300 & 41 & $0+766$ & 2004.500 & 2289.420 \\
\hline 18 & $1+824$ & 4221.500 & 3828.440 & Total & $146+906$ & 349915.800 & 312479.400 \\
\hline
\end{tabular}

With the consideration of only the areas to be afforested and wood production per hectare, total length of forest roads has been calculated to be $92+435 \mathrm{~km}$. However, due to the fact that the land and the flora is patched scattered; and mechanical deportation is not possible, road distance has been designated as $500-1000 \mathrm{~m}$ for purposes of the most economic extraction of forest products out of partitions; to shorten primary transport distances and facilitate the prevention of forest fires and insect invasions. Thus, the total planned road length has been calculated as $146+906 \mathrm{~km}$ and road density as $19,54 \mathrm{~m} / \mathrm{ha}$.

All roads included in the forest road network plan have been screened on the computer (Fig. 4-6). With the completion of works for the roads included in the forest road network plan, equal access will be ensured throughout the forest; thus facilitating the realization of production, recreation, forestation and fire fighting activities.

\section{ACKNOWLEDGEMENTS}

This work was supported by the Research Fund of the University of Istanbul, Project Number: UDP335/09062004.

\section{REFERENCES}

1. Aykut, T., N. Senturk and M. Demir, 1998. Situations on Turkish forest roads in $75_{\text {th }}$ years of the Republic of Turkey. Symposiums of the Turkish Forestry in $75_{\text {th }}$ Years of the Republic of Turkey, Istanbul, Turkey. 
2. Aykut, T., M. Demir and H.H. Acar, 2000. Designing forest road network and transportation plans in the computer. Proceedings of the International Conference Forest and Wood Technology vs. Environment, pp: 35-42, 20th-22nd Oct. 2000, Brno, Czech Republic.

3. Demir, M., 1999. The importance and effects of forest transportation plan at the mountain region. Review of the Faculty of Forestry, University of Istanbul Series B, Vol. 47: 1-2-3-4, 1997, Istanbul, Turkey.

4. Demir, M., 2002. Computer aided forest road network and transportation planning in Bolu region. Ph.D Thesis, University of Istanbul, Faculty of Forestry, Istanbul, Turkey.

5. Demir, M. and T. Ozturk, 2002. The evaluation of forest roads in Turkey. International Conference Logistics of Wood Technical Production in the Carpathian Mountains, pp: 39-45, ISBN 80-2281170-X, Zvolen, The Slovak Republic.

6. SIS, 2004. The Prime Ministry State Institute of Statistics (SIS) of The Republic of Turkey. www.die.gov.tr, Ankara, Turkey.

7. GDF, 2004. Turkish General Directorate of Forestry, www.ogm.gov.tr, Ankara, Turkey.
8. Hasdemir, M. and M. Demir, 2001. The condition and evaluation of forest roads in Turkey. Third Balkan Scientific Conference, Ivpp: 268-276, ISBN 954-90896-5-7, 02nd-06 ${ }^{\text {th }}$ Oct. 2001, Sofia, Bulgaria.

9. Hasdemir, M. and M. Demir, 1997. A model of forest road network planning based on geographic information systems. Review of the Faculty of Forestry, University of Istanbul, Series B, Vol. 44: 3-4, 1994, Istanbul, Turkey.

10. Hasdemir, M. and M. Demir, 1998. Computer aided forest road planning. Symposiums of the Turkish Forestry in $75_{\text {th }}$ Years of the Republic of Turkey, $21_{\mathrm{st}-23 r d}$ Oct.1998, Istanbul, Turkey.

11. Senturk, N., 1992. The possibility of using the digital data in the planning of forest roads. Ph. D Thesis, University of Istanbul, Faculty of Forestry, Istanbul, Turkey.

12. FCR, 2001. Turkish Commission Report, The Prime Ministry State Planning Organization of the Republic of Turkey Publication Number: 2531/547, Ankara, Turkey. 